\title{
Pengaruh Gaya Hidup Konsumtif dan Kualitas Produk Terhadap Keputusan Pembelian
}

\author{
Eni Nur Aini' ${ }^{1}$, Anik Lestari Andjarwati ${ }^{2}$ \\ Universitas Negeri Surabaya $^{1}$, Universitas Negeri Surabaya ${ }^{2}$ \\ eniaini@mhs. unesa.ac.id ${ }^{1}$, aniklestari@unesa.ac.id ${ }^{2}$
}

\begin{abstract}
Along with the development of the hijab model in Indonesia which is a market need and can develop the creativity of fashionable hijab. From year to year Zoya continues to provide new creations and innovations to her hijab designs. Ranging from exclusive designs to promotional materials that continue to give priority to the comfort of its users. Various awards ranging from Top Brand to Best Band achieved in three years were agreed. Based on this phenomenon, this study discusses the consumptive lifestyle and product quality on Zoya hijab purchasing decisions in Central Surabaya. This research method uses quantitative methods by studying causal with multiple linear regression techniques using the IBM SPSS 23 for windows program. Consumptive lifestyle and product quality as independent variables and purchasing decisions as the dependent variable. The object of this research is the Zoya brand quadrilateral consumers with a sample of 220 respondents. The results showed that the consumptive lifestyle influenced purchasing decisions by 0.225 , but the results differed on the product quality variable by 0.080 that did not affect the purchasing decision.
\end{abstract}

Keywords: Consumptive Behavior, Consumptive Lifestyle, Product Quality, Purchasing Decisions, Fashion, Hijab

\begin{abstract}
Abstrak
Seiring dengan perkembangan hijab fashion di Indonesia yang menjadi kebutuhan dasar pasar dan dapat mengembangkan kreatifitas jilbab yang fashionable. Dari tahun ke tahun Zoya terus memberikan kreasi dan inovasi baru pada desain jilbabnya. Mulai dari desain yang eksklusif hingga inovasi bahan yang terus mengutamakan kenyamanan penggunanya. Berbagai penghargaan mulai dari Top Brand hingga Best Band diraih dalam tiga tahun berturut-turut. Berdasarkan fenomena ini, penelitian ini bertujuan untuk mengetahui pengaruh gaya hidup konsumtif dan kualitas produk terhadap keputusan pembelian jilbab Zoya di Surabaya Pusat. Metode penelitian ini menggunakan metode kuantitatif dengan pendekatan kausal dengan teknik regresi linier berganda dengan menggunakan program IBM SPSS 23 for windows. Gaya hidup konsumtif dan kualitas produk sebagai variabel independen dan keputusan pembelian sebagai variabel dependen. Objek penelitian ini adalah konsumen jilbab segi empat merk Zoya dengan sampel 220 responden. Hasil penelitian menunjukkan bahwa gaya hidup konsumtif berpengaruh terhadap keputusan pembelian sebesar 0,225, namun hasil berbeda pada variabel kualitas produk sebesar 0,080 bahwa tidak mempengaruhi terhadap keputusan pembelian.
\end{abstract}

Kata Kunci: Perilaku Konsumtif, Gaya Hidup Konsumtif, Kualitas Produk, Keputusan Pembelian, Fashion, Hijab 


\section{PENDAHULUAN}

Ketika pola pikir manusia semakin berkembang khususnya di kalangan perempuan muslim, penutup aurat yang dinamakan jilbab bukan lagi sesuatu yang dipandang aneh. Hijab telah menjadi bagian gaya hidup bagi banyak perempuan muslim di Indonesia. Sudah banyak publik figure yang mengenakan jilbab, sehingga jilbab dengan cepatnya menjamur di kalangan masyarakat luas. Fenomena hijab nampaknya semakin menjadi bagian dari gaya hidup. Trend tersebut semakin diminati khususnya kalangan muda perkotaan sehingga memunculkan identitas baru, bahkan menjadi bagian dari budaya. Dimana tujuan utama berjilbab bukan lagi untuk menutupi aurat, tetapi dijadikan suatu trend fashion baru dikalangan masyarakat. Kini sifat konsumerisme telah menjadi gaya hidup yang mempengaruhi kehidupan masyarakat. Perilaku konsumtif menjadi sangat kompleks di tengah kebutuhan hidup yang melonjak dan yang diingat hanya bagaimana cara memuaskan hasrat belanja.

Adanya perubahan gaya hidup dari generasai ke generasi menjadi perubahan sosial di masyarakat dan lingkungan ekonomi, merupakan peluang yang baik bagi pemasar untuk menyesuaikan produknya sesuai dengan gaya hidup pasar yang akan dituju (Hana, 2019). Menurut beberapa pakar, kebutuhan jilbab sebagai sarana fashion akhirnya mendorong banyak wanita di Indonesia melakukan revolusi jilbab dengan menciptakan berbagai model jilbab yang lebih sesuai, mulai dari gaya simple, gaya untuk pesta, dan berbagai variasi lainnya.

Berdasarkan Sumarwan (2015: 10) mengungkapkan bahwa proses keputusan konsumen dipengaruhi tiga faktor utama, yaitu : perbedaan individu, strategi pemasaran dan faktor lingkungan. Salah satu faktor yang mempengaruhi perilaku konsumen adalah strategi pemasaran. (Engel, Blackwell, \& Miniard, 1995: 141) mengatakan bahwa keputusan pembelian dipengaruhi oleh faktor internal yang terdiri dari faktor lingkungan dan perbedaan individu. Pengaruh lingkungan terdiri atas budaya, kelas sosial, keluarga, pribadi dan situasi. Untuk faktor individu meliputi sumber daya konsumen, motivasi, pengetahuan, sikap, kepribadian, gaya hidup dan demografi. Sedangkan faktor eksternal seperti marketing mix meliputi product, price, place, promotion. Setelah konsumen melakukan pembelian, maka timbullah hasil yang mengarah pada kepuasan dan ketidakpuasan.

Faktor yang mempengaruhi keputusan pembelian adalah perbedaan individu (Engel, Blackwell, \& Miniard, 1995: 141). Perbedaan individu menggambarkan faktor-faktor karakteristik individu yang muncul dari dalam diri konsumen dan proses psikologis yang terjadi pada diri konsumen yang sangat berpengaruh terhadap proses keputusan konsumen (Sumarwan, 2015:10). Disebutkan bahwa salah satu bentuk dari perbedaan individu konsumen adalah gaya hidup. Gaya hidup sendiri adalah pola pikir seseorang dalam bereaksi dan berinteraksi di dunia yang tercermin dalam aktivitas, minat, dan opini (Kotler \& Keller, 2009: 175). 
Sumartono dalam Syaiful (2012), menjelaskan gaya hidup konsumtif merupakan suatu tindakan menggunakan suatu produk serta tidak tuntas. Artinya belum habis suatu produk dipakai, seorang telah menggunakan produk lain dengan fungsi yang sama. Anggasari dalam Hotpascaman (2010) mendefinisikan perilaku konsumtif adalah tindakan membeli barang-barang yang kurang atau tidak diperhitungkan sehingga sifatnya kurang atau tidak diperhitungkan. Kamus Besar Bahasa Indonesia mendefinisikan konsumerisme sebagai paham atau gaya hidup yang menganggap barangbarang sebagai untuk kebahagiaan, kesenangan, dan sebagainya.

Berdasarkan penelitian terdahulu tentang gaya hidup konsumtif dan keputusan pembelian, Faadhilah (2018) menunjukkan bahwa gaya hidup konsumtif berpengaruh terhadap keputusan pembelian. Hal ini juga didukung oleh penelitian Pramudi (2015) mengungkapkan bahwa gaya hidup konsumtif berpengaruh dalam mempengaruhi keputusan pembelian dari konsumen. namun berbeda dengan kedua penelitian tersebut, Enricoet al (2014) menunjukkan bahwa perilaku konsumtif tidak berpengaruh terhadap keputusan pembelian. Hal ini di dukung oleh penelitian Oktari (2014) bahwa gaya hidup konsumtif mempunyai pengaruh negatif terhadap keputusan pembelian. Sehingga terdapat reserch gap pada pengaruh gaya hidup konsumtif terhadap keputusan pembelian.

Faktor pendorong lain yang mempengaruhi keputusan pembelian adalah produk. Pada produk terdapat atribut produk antara lain terdiri dari fitur produk, gaya dan desain, serta kualitas produk. Tjiptono (2010: 103) menyatakan bahwa atribut produk adalah unsur-unsur produk yang dipandang penting oleh konsumen dan dasar pengambilan keputusan pembelian.

Berdasarkan Kotler \& Keller (2012: 352) produk yang dihasilkan dengan kualitas yang baik maka akan menarik konsumen untuk melakukan pembelian, konsumen akan melakukan pertimbangan saat membeli, salah satunya memilih produk yang memiliki kualitas yang baik, perusahaan yang meningkatkan kualitas produk dapat menghasilkan tingkat pengambilan keputusan. Hal ini juga didukung oleh penelitian yang dilakukan oleh Andriati (2016) bahwa kualitas produk berpengaruh signifikan terhadap keputusan pembelian. Diperkuat oleh penelitian yang dilakukan Dian et al (2019) dan Ayuningtyas (2015) menunjukkan bahwa kualitas produk berpengaruh signifikan terhadap keputusan pembelian. Namun berbeda dengan penelitian yang dilakukan oleh Supriyadi dkk (2016) menunjukkan bahwa kualitas produk tidak berpengaruh terhadap keputusan pembelian. Sehingga terdapat research gap pada pengaruh kualitas produk terhadap keputusan pembelian.

Zoya adalah salah satu brand muslim yang menjadi pioner hijab dan pakaian muslim di Indonesia. Berdiri sejak 2005, Zoya telah memiliki lebih dari 160 toko tersebar luas di seluruh Indonesia. Dari tahun ke tahun Zoya terus memberikan kreasi dan inovasi baru pada desain hijab serta busana muslimnya dari desainer-desainer terbaik Indonesia. Mulai dari desain yang 
ekslusif hingga inovasi bahan yang terus mengutamakan kenyamanan penggunanya. Setelah menjadi penggagas hijab halal, Zoya juga menghadirkan HEIQ yakni teknologi dari Swiss yang bisa mengatur suhu dan menyerap panas. Hadir untuk menyempurnakan penampilan cantik paras muslimah Indonesia. Hijab Zoya tetap mengutamakan kenyamanan, pilihan motif dan warna beragam serta membuat penggunanya semakin percaya diri dan cantik.

Berbagai penghargaan mulai dari Top Brand hingga Best Brand di raih dalam tiga tahun berturut-turut, dan Zoya kini menjadi brand muslim pertama yang memiliki label halal serta mempertahankan kualitas dari produk yang diunggulkan. Kelebihan dari jilbab Zoya dapat diketahui bahwa edisi jilbab Zoya sangat terbatas, dengan tren hijab sampai setahun ke depan yang bersertifikat halal pada bahan yang digunakannya, hijabnya memiliki kualitas nyaman dipakai dengan kualitas yang sangat elegan dengan berbagai motif dan dapat dipadukan dengan aksesoris.

Berdasarkan latar belakang tersebut maka tujuan penelitian ini adalah untuk menganalisis dan mambahas pengaruh gaya hidup konsumtif dan kualitas produk terhadap keputusan pembelian (studi pada konsumen jilbab Zoya di Surabaya Pusat).

\section{KAJIAN LITERATUR \\ Perilaku Konsumen}

Perilaku konsumen menurut (Kotler \& Keller, 2012: 151), "Perilaku konsumen merupakan studi tentang bagaimana seseorang individu, kelompok, dan organisasi memilih, membeli, menggunakan, dan bagaimana barang, dan juga jasa, ide, atau sebuah pengalaman untuk memuaskan kebutuhan dan keinginan mereka".

Engel et al, (1995) dalam buku Sumarwan (2015: 4), perilaku konsumen adalah sebagai tindakan yang langsung terlibat dalam mendapatkan, mengkonsumsi, dan menghabiskan produk dan jasa, termasuk dalam proses keputusan yang mendahului dan mengikuti tindakan ini.

Berdasarkan beberapa teori yang dikemukakan oleh para ahli di atas dapat disimpulkan bahwa perilaku konsumen merupakan semua tindakan yang dilakukan konsumen baik individu maupun kelompok pada saat membeli, ketika membeli, dan setelah membeli guna memuaskan kebutuhan mereka.

\section{Keputusan Pembelian}

Menurut Kotler \& Keller (2012: 178) menyatakan bahwa proses psikologis dasar memainkan peranan penting dalam memahami bagaimana konsumen benar-benar membuat keputusan pembelian mereka.

Menurut Shiffman dan Kanuk dalam Sumarwan (2015: 357), keputusan pembelian sebagai pemilihan suatu tindakan dari dua atau lebih pilihan alternatif. Seseorang konsumen yang hendak melakukan pilihan maka ia harus memiliki pilihan alternatif. Pengambilan keputusan oleh konsumen 
dalam membeli suatu barang atau jasa tentunya berbeda, tergantung pada jenis keputusan pembelian apa yang diinginkannya.

Berdasarkan pernyataan dari beberapa ahli di atas, maka keputusan pembelian dapat dinyatakan sebagai proses dimana konsumen dihadapkan pada beberapa pilihan dan kemudian memutuskan untuk membeli produk yang ditawarkan. Serta dipengaruhi oleh strategi pemasaran, perbedaan individu, dan faktor lingkungan.

\section{Gaya Hidup Konsumtif}

Perilaku konsumtif menurut Sumartono (2002: 117) merupakan tindakan memakai produk secara tidak tuntas dimana sebuah produk yang dipakai belum habis, tetapi orang tersebut menggunakan produk dengan jenis yang sama namun berbeda merek.

Sumartono dalam Syaiful (2012), menjelaskan gaya hidup konsumtif merupakan suatu tindakan menggunakan suatu produk serta tidak tuntas. Artinya belum habis suatu produk dipakai, seorang telah menggunakan produk lain dengan fungsi yang sama. Hal ini tentunya akan menghabiskan pengeluaran individu lebih banyak. Dari pendapat diatas ditarik kesimpulan bahwa gaya hidup konsumtif merupakan suatu perilaku yang ditandai adanya kehidupan mewah dan berlebihan. Dari perilaku konsumtif inilah yang menyebabkan seseorang menjadi pribadi yang bergaya hidup konsumtif.

\section{Kualitas Produk}

Menurut Kotler \& Keller (2012: 143) menyatakan bahwa kualitas produk adalah kemampuan suatu barang untuk memberikan hasil atau kinerja yang sesuai bahkan melebihi apa yang diinginkan pelanggan.

Berdasarkan definisi American Society dalam Kotler \& Keller (2012: 143) mendefinisikan sebagai berikut Quality is the totality of features and characteristivs of a product or service that bear on its ability to satisify stated or implied needs ungkapan ini dapat diartikan bahwa kualitas adalah totalitas fitur dan karakteristik dari produk atau layanan yang menanggung pada kemampuannya untuk memusakan atau memenuhi kebutuhan. Berdasarkan teori dari Sutisna (2002: 26), "pemahaman konsumen tentang kualitas produk dapat dijadikan dasar terhadap proses keputusan pembelian konsumen".

Berdasarkan beberapa definisi di atas dapat disimpulkan bahwa kualitas produk adalah satu keseluruhan ciri atau jasa yang dimiliki suatu produk atau jasa yang mampu memenuhi fungsi-fungsinya sehingga dapat memberikan kepuasan bagi konsumen dan melakukan keputusan pembelian.

\section{Hipotesis}

H1 : Ada pengaruh gaya hidup konsumtif terhadap keputusan pembelian

H2 : Ada pengaruh kualitas produk terhadap keputusan pembelian 


\section{METODE PENELITIAN}

Jenis penelitian yang digunakan dalam penelitian ini adalah penelitian kuantitatif. Rancangan penelitian pada penelitian ini adalah konklusif. Adapun populasi dalam penelitian ini adalah konsumen wanita yang berusia 18-35 tahun dan konsumen yang pernah membeli jilbab segi empat Zoya minimal dua kali pembelian. Jumlah sampel yang digunakan sebesar 220 responden. Teknik pengambilan sampel menggunakan judgemental sampling. Skala yang digunakan adalah skala likert. Skala likert adalah pengukuran dengan lima kategori respon yang berkisar antara tidak setuju hingga sangat setuju. Penyebaran angket pada penelitian ini dilakukan di Surabaya Pusat. Data yang diperoleh dari angket penelitian ini selanjutnya

\section{PEMBAHASAN}

\section{Uji Instrumen}

Dalam penelitian ini berdasarkan pengujian validitas dari seluruh indikator pertanyaan dinyatakan valid dengan Corrected Item-Total Correlation $\mathrm{r}$ hitung $>r$ tabel dengan nilai 0,361. Berdasarkan uji Reliabilitas dari semua indikator pertanyaan dalam penelitian ini dinyatakan realible bahwa nilai Cronbach's Alpha > 0,70 sehingga bisa dikatakan hasil pengukuran tetap konsisten.

\section{Analisis Regresi Linier}

Model analisis regresi berganda ini dipakai untuk mengetahui peran variabel independen (gaya hidup konsumtif dan kualitas produk) terhadap variabel dependen (keputusan pembelian). Hasil pengolahan data menggunakan program SPSS 23 for windows.

\section{Tabel 1}

\section{Coefficients $^{\mathrm{a}}$}

Hasil Analisis Regresi Linier Berganda Coefficients ${ }^{2}$

\begin{tabular}{|c|c|c|c|c|c|c|}
\hline & \multicolumn{2}{|c|}{$\begin{array}{l}\text { Unstandardized } \\
\text { Coefficients }\end{array}$} & \multirow{2}{*}{\begin{tabular}{|l|} 
Standardized \\
Coefficients \\
Beta \\
\end{tabular}} & \multirow[b]{2}{*}{$\mathrm{t}$} & \multirow[b]{2}{*}{ Sig. } \\
\hline & & B & Std. Error & & & \\
\hline \multirow[t]{3}{*}{1} & (Constant) & .511 & 1.966 & & .260 & .795 \\
\hline & TOTAL.X1 & .255 & .029 & .606 & 8.679 & .000 \\
\hline & TOTAL.X2 & .080 & .057 & .099 & 1.415 & 158 \\
\hline
\end{tabular}

a. Dependent Variable: Keputusan

Pembelian

Sumber : data diolah oleh peneliti

1. Variabel gaya hidup konsumtif $\left(\mathrm{X}_{1}\right)$ senilai 0,255 , menggambarkan bahwa gaya hidup konsumtif mempunyai nilai positif menunjukkan jika Gaya hidup konsumtif dan Keputusan pembelian memiliki hubungan yang searah, artinya semakin baik Gaya hidup konsumtif yang diberikan oleh jilbab Zoya maka akan semakin tinggi Keputusan pembelian terhadap jilbab Zoya. 
2. Variabel kualitas produk $\left(\mathrm{X}_{2}\right)$ senilai 0,080 , menggambarkan bahwa kualitas produk mempunyai nilai positif menunjukkan jila kualitas produk dan keputusan pembelian memiliki hubungan yang searah artinya arti apabila Kualitas produk yang diberikan oleh jilbab Zoya besar atau ditingkatkan maka Keputusan pembelian konsumen terhadap jilbab Zoya juga akan meningkat.

\section{Hasil Uji Koefisien Determinasi}

\begin{tabular}{|c|c|c|c|c|}
\hline \multicolumn{5}{|c|}{$\begin{array}{c}\text { Tabel } 2 \\
\text { Nilai Adjusted R Square } \\
\text { Model Summaryb }\end{array}$} \\
\hline Model & $\mathrm{R}$ & $\begin{array}{l}\mathrm{R} \\
\text { Square }\end{array}$ & $\begin{array}{l}\text { Adjusted } \\
\text { R Square }\end{array}$ & $\begin{array}{l}\text { Std. Error of } \\
\text { the Estimate }\end{array}$ \\
\hline 1 & $.678^{a}$ & .460 & .455 & 3.382 \\
\hline
\end{tabular}

Berdasarkan tabel 2 adalah hasil kontribusi dari variabel independen yakni Gaya hidup konsumtif $\left(\mathrm{X}_{1}\right)$ dan Kualitas produk $\left(\mathrm{X}_{2}\right)$ terhadap Keputusan pembelian $\left(\mathrm{Y}\right.$ ) dengan nilai adjusted $\mathrm{R}^{2}$ adalah sebesar $0.455=45,5 \%$. Dari nilai tersebut menunjukkan bahwa Gaya hidup konsumtif $\left(\mathrm{X}_{1}\right)$ dan Kualitas produk $\left(\mathrm{X}_{2}\right)$ mempengaruhi Keputusan pembelian jilbab Zoya sebanyak 45,5\%. Sedangkan sisanya 54,5\% dipengaruhi oleh variabel lainnya diluar variabel yang digunakan dalam penelitian ini.

\section{Hasil Uji Hipotesis dengan Uji t}

Hasil perhitungan nilai $\mathrm{t}$ hitung variabel Gaya hidup konsumtif sebesar 8.679 dan di dukung nilai signifikansi sebesar .000<0,05 atau 5\%. Maka dapat disimpulkan $\mathrm{H}_{0}$ ditolak dan $\mathrm{H}_{1}$ diterima, sehingga dapat dijelaskan bahwa variabel gaya hidup konsumtif memiliki pengaruh secara signifikan terhadap keputusan pembelian.

Sedangkan kualitas produk sebesar 1.415 dan di dukung nilai signifikansi sebesar $0.158>0,05$ atau 5\%. Maka dapat disimpulkan $\mathrm{H}_{0}$ diterima dan $\mathrm{H}_{1}$ ditolak, sehingga dapat disimpulkan bahwa variabel kualitas produk tidak memiliki pengaruh secara signifikan terhadap keputusan pembelian.

\section{Pengaruh Gaya hidup konsumtif terhadap Keputusan pembelian}

Hasil penelitian ini membuktikan konsep teori dari Sumartono (2002:117) mendefinisikan bahwa perilaku konsumtif merupakan tindakan yang memakai produk secara tidak tuntas, dimana sebuah produk yang dipakai belum habis tetapi orang tersebut menggunakan produk dengan jenis yang sama namun berbeda merek.

Penelitian ini mendukung penelitian terdahulu yang dilakukan oleh Faadhilah (2018) bahwa gaya hidup konsumtif berpengaruh positif dan 
signifikan terhadap keputusan pembelian kosmetik. Hal ini sejalan dengan penelitian yang dilakukan Pramudi (2015) bahwa gaya hidup konsumtif berpengaruh terhadap keputusan pembelian. Namun hasil penelitian ini tidak mendukung penelitian terdahulu yang dilakukan oleh Enrico et al (2014) karena terdapat perbedaan indikator yang digunakan yaitu membeli produk tanpa menggunakannya sedangkan penelitian ini tidak menggunakan indikator membeli produk tanpa menggunakannya.

Dari penelitian ini, peneliti memperoleh hasil yang menunjukkan bahwa adanya pengaruh secara signifikan pada variabel Gaya hidup konsumtif terhadap variabel Keputusan pembelian. Artinya Gaya hidup konsumtif sebagai variabel yang memberi pengaruh terhadap Keputusan pembelian. Hasil tersebut menunjukkan bahwa semakin tinggi Gaya hidup konsumtif dari jilbab Zoya maka semakin tinggi juga tingkat keputusan pembelian. Hal tersebut berkaitan dengan produk jilbab segi empat merek Zoya yang merupakan pioner hijab muslim Indonesia yang setiap tahunnya memberikan kreasi dan inovasi baru pada desain jilbabnya mulai dari desain yang ekslusif hingga inovasi bahan yang mengutamakan kenyamanan penggunanya. Zoya juga menghadirkan HEIQ yakni teknologi dari Swiss yang bisa mengatur suhu dan dapat menyerap panas. Selain itu jilbab segi empat Zoya hadir dengan beragam pilihan motif dan warna, sehingga membuat konsumen lebih tertarik lagi untuk membeli.

Gaya hidup konsumtif pada penelitian ini diukur dengan menggunakan sembilan indikator yaitu membeli produk untuk koleksi (berbeda warna tetapi dengan fungsi yang sama), membeli produk yang biasanya digunakan kalangan menengah ke atas, membeli produk yang mempunyai reputasi baik, merasa malu apabila tidak memiliki produk bagus, keluarga selalu mengingatkan untuk membeli produk berdasarkan kualitas bagus, gaya berpenampilan, penggunaan jilbab, membeli produk demi menjaga penampilan dan gengsi, membeli produk hanya sekedar simbol status. Dari sembilan indikator tersebut responden memiliki rata-rata setuju dengan item pertanyaan yang memiliki nilai tertinggi yakni "Saya tertarik dengan edisi jilbab Zoya yang terbaru" yang artinya rata-rata responden tertarik dengan edisi jilbab Zoya yang terbaru. Hal ini dikarenakan jilbab segi empat Zoya setiap tahunnya memberikan kreasi dan inovasi baru, mulai dari desain yang eksklusif hingga inovasi bahan dan yang mengutamakan kenyamanan para penggunanya. Sehingga hal ini menjadikan alasan bagi responden yang membuat tertarik dalam membeli jilbab Zoya dengan edisi terbaru dalam melakukan keputusan pembelian.

\section{Pengaruh Kualitas produk Terhadap Keputusan pembelian}

Dari penelitian ini, peneliti memperoleh hasil yang menunjukkan bahwa tidak ada pengaruh secara signifikan variabel Kualitas produk terhadap Keputusan pembelian. Hal ini mengartikan bahwa apabila terjadi peningkatan Kualitas produk yang diberikan, maka tidak akan mempengaruhi Keputusan pembelian. Sehingga hal ini tidak membuktikan 
teori yang dikemukakan oleh Sutisna (2002). Penelitian ini mendukung teori dari definisi American Society dalam Kotler \& Keller (2012: 156) mendefinisikan bahwa kualitas adalah totalitas fitur dan karakteristik dari produk atau layanan yang menanggung pada kemampuannya untuk memuaskan atau memenuhi kebutuhan.

Hasil penelitian ini mendukung penelitian yang dilakukan oleh Supriyadi dkk (2016) dengan hasil bahwa kualitas produk tidak berpengaruh secara signifikan terhadap keputusan pembelian. Namun penelitian ini tidak mendukung penelitian yang dilakukan oleh Andriati (2016) dan Soepeno (2015) bahwa kualitas produk berpengaruh secara signifikan terhadap keputusan pembelian. Pada penelitian ini kualitas produk menggunakan lima indikator yaitu presepsi terhadap kualitas, model produk yang sesuai trend pasar, nyaman dipakai, keistimewaan tambahan, dan model.

Dari lima indikator tersebut memiliki nilai rata-rata yang terendah yakni dengan item pernyataan "Saya membeli jilbab Zoya agar tidak dianggap ketinggalan zaman" artinya bahwa responden tidak melihat kualitas produk ketika ingin melakukan keputusan pembelian dan dapat dilihat dari hasil karakteristik pada penelitian ini. Dengan hasil presentase pembelian sebanyak 3 kali pembelian jilbab Zoya yang membuat respondennya cenderung lebih mengutamakan tren dibandingkan dengan kualitas yang diberikan oleh jilbab Zoya.

Responden pada penelitian ini di dominasi dengan rentan usia 25-30 tahun yang merupakan generasi Y. Generasi Y merupakan generasi yang terlahir di era globalisasi, generasi $\mathrm{Y}$ cenderung mengikuti apa yang sedang menjadi tren di masyarakat. Artinya seseorang yang sedang mengikuti tren jilbab kekinian dikalangan masyarakat dan seseorang tersebut membeli jilbab Zoya karena hanya ingin mengikuti perkembangan yang terjadi saat ini, sehingga bersifat konsumtif dalam melakukan keputusan pembelian. Oleh karena itu dalam pembahasan ini, generasi $Y$ cenderung mengutamakan trend dibandingkan kualitas. Bahwa konsumen yang membeli jilbab Zoya hanya ingin mengikuti edisi jilbab Zoya yang terbaru agar tidak dianggap ketinggalan zaman dan tanpa melihat kualitas dari jilbab tersebut. Sehingga kualitas produk tidak menjadi pengaruh utama dalam keputusan pembelian. Berdasarkan hasil analisis dan pembahasan pada penelitian ini dapat disimpulkan bahwa pada variabel gaya hidup konsumtif memiliki pengaruh signifikan terhadap keputusan pembelian. Sedangkan terdapat hasil yang berbeda dari variabel kualitas produk dimana pada variabel kualitas produk tidak berpengaruh signifikan terhadap keputusan pembelian. Hal ini mengisyaratkan bahwa konsumen jilbab Zoya lebih memilih melakukan pembelian atas dasar pengaruh gaya hidup konsumtif yang dinilai cukup membantu dalam berpenampilan yang lebih mengutamakan keinginan dibandingkan dengan kualitas dari jilbab Zoya. 


\section{SIMPULAN}

Berdasarkan hasil analisis dan pembahasan pada penelitian ini dapat disimpulkan bahwa pada variabel gaya hidup konsumtif memiliki pengaruh signifikan terhadap keputusan pembelian. Sedangkan variabel kualitas produk terdapat hasil yang berbeda dimana pada variabel kualitas produk tidak berpengaruh signifikan terhadap keputusan pembelian. Hal ini mengisyaratkan bahwa konsumen jilbab Zoya lebih memilih melakukan pembelian atas dasar pengaruh gaya hidup konsumtif yang dinilai cukup membantu dalam berpenampilan yang lebih mengutamakan keinginan dibandingkan dengan kualitas dari jilbab Zoya.

\section{DAFTAR PUSTAKA}

Achmad Syaiful Ramadhan. (2012). Hubungan Gaya Hidup Konsumtif Harga Diri Mahasiwa Fakultas Psikologi Universitas "X."

Andriati, C. (2016). Analisis Pengaruh Harga, Kualitas Produk, Kualitas Pelayanan dan Citra Merek Terhadap Kpeutusan Pembelian Sepatu Bata (Studi pada Konsumen Sepatu Bata Semarang). IOSR Journal of Economics and Finance, 3(1), 56. https://doi.org/https://doi.org/10.3929/ethz-b-000238666

Ayuningtyas, L. D. (2015). Pengaruh Harga, Promosi, Merek, dan Kualitas Produk Terhadap Keputusan Pembelian Jilbab Elzatta di Royal Plaza Surabaya. 3.

Dian, S., \& Prajanti, W. (2019). Predicted Purchasing Decisions from Lifestyle, Product Quality and Price Through Purchase Motivation. 8(1), 1-11.

Engel, J. ., Blackwell, R. ., \& Miniard, P. . (1995). Consumer Behaviour. 8th Ed. Forth Worth, Texas: The Drydeb Press.

Enrico, A., Aron, R., \& Oktavia, W. (2014). The Factors that Influenced Consumptive Behavior: A Survey of University Students in Jakarta. 4(1), 2014.

Faadhilah, F. N. (2018). Pengaruh gaya hidup konsumtif dan beauty vlogger sebagai kelompok referensi terhadap keputusan pembelian kosmetik (studi pada remaja perempuan pengguna kosmetik korea di surabaya). 7 , 133-142.

Hana, K. F. (2019). Minat Beli Online Generasi Milenial: Pengaruh Kepercayaan dan Kualitas Layanan. BISNIS: Jurnal Bisnis Dan Manajemen Islam, $\quad 7(2), \quad 203-216 . \quad$ Retrieved from http://journal.iainkudus.ac.id/index.php/bisnis/index

James F. Engel, Roger D. Blackwell, P. W. M. (1995). Perilaku Konsumen (keenam; B. Aksara, ed.). Jakarta.

Kotler, P., \& Keller, K. L. (2009). Manajemen Pemasaran, Edisi 13 Jilid 1\&2. Jakarta: Erlangga.

Kotler, P., \& Keller, K. L. (2012). Manajemen Pemasaran (13th ed.; A. Maulana $\&$ Y. S. Hayati, eds.). Jakarta.

Oktari. (2014). Keputusan Pembelian Perhiasan Emas Pada Pelanggan Toko Emas Di Kawasan Banjarmasin. Jurnal Ecopsy, (4), 1-5. 
Pramudi, R. Y. (2015). Pengaruh Gaya Hidup Konsumtif Dan Kelompok Referensi. Jurnal Universitas Negeri Surabaya, 15(2), 280-301.

Sumartono. (2002). Terperangkap dalam Iklan (Meneropong Imbas Pesan Iklan Televisi) (Alfabeta). Bandung.

Sumarwan, U. (2015). Perilaku Konsumen: Teori dan Penerapannya dalam Pemasaran (2nd ed.; R. Sikumbang, ed.). Bogor.

Syaiful Ramadhan, A. (2012). Hubungan Gaya Hidup Konsumtif Dengan Harga Diri Mahasiswa Fakultas Psikologi Universitas "X."

Tjiptono, \& Fandy dan Gregorius Chandra. (2010). Pemasaran Strategik (Andi, ed.). Yogjakarta.

Widodo, 0. W. (2012). Analisis pengaruh kualitas produk, kualitas layanan, dan promosi terhadap keputusan pembelian. 
Eni Nur Aini dan Anik Lestari Andjarwati

Halaman ini sengaja dikosongkan 